

\section{Contact and Application}

If you are interested in this program, visit one of our homepages:

www.biomedmaster.org and

www.ffyb.uba.ar

or contact us via email.

info@biomedmaster.org and

imbs@ffyb.uba.ar

For further information about the application to this program contact

\section{University of Freiburg}

c/o Prof. Dr. Christoph Borner

Project Coordinator International Master/

$\mathrm{PhD}$ Program in Biomedical Sciences

Institute of Molecular Medicine and Cell Research

Stefan-Meier-Str. 17

D - 79104 Freiburg

phone: $\quad+4976120397489$

fax: $\quad+497612039620$

e-mail: imbs@mol-med.uni-freiburg.de

or

Universidad de Buenos Aires

c/o Prof. Dr. Daniel Turyn - Dr. Marta Mollerach

Facultad de Farmacia y Bioquímica

Junin 956, Planta Principa

Ciudad Autónoma de Buenos Aires

C1113AAD, Argentina.

phone: (+5411) 4964-82 29

e-mail: imbs@ffyb.uba.ar

Supported by:

DA $A D$ German Academic Exchange Service

\section{www daad de}

息
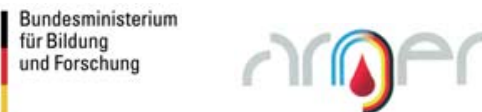

www.bmbf de
Freiburg:

Prof. Dr. Christoph Borne

Program Director Freiburg

christoph.borner@uniklinik-freiburg.de

Prof. em. Dr. Drs. h.c. Roland Mertelsmann Co-Program Director Freiburg

roland.mertelsmann@uniklinik-freiburg.de

\section{Buenos Aires}

Prof. Dr. Cristina Arranz

Program Director Buenos Aires carranze@ffyb.uba.ar

Prof. Dr. Ricardo Gelpi

IMBS Committee Buenos Aires rgelpi@fmed.uba.ar

Prof. Dr. de Nicola

IMBS Committee Buenos Aires

denicola@dna.uba.ar

\section{Prof. Dra. Marta Mollerach}

IMBS Committee Buenos Aires

mmollera@ffyb.uba.ar

\section{Tamara Ferreiro}

IMBS Secretary Buenos Aires

imbs@ffyb.uba.ar
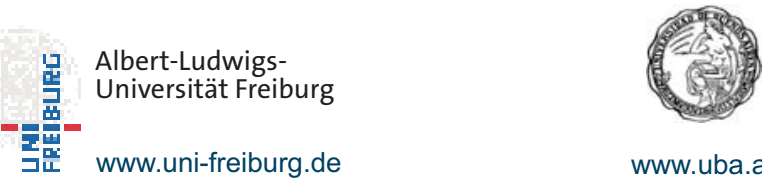

www.uba.ar

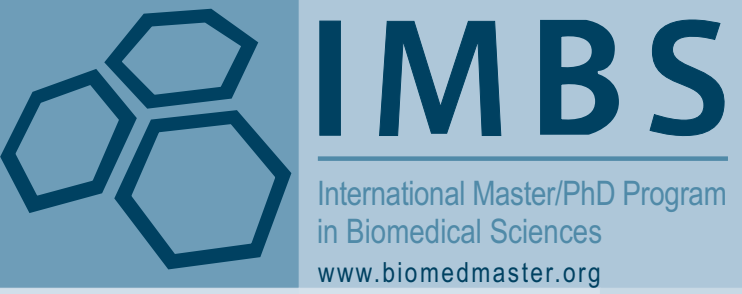

INFORMATION

A joint program of the

Albert-Ludwigs-University of Freiburg (Germany) and the University of Buenos Aires (Argentina)

\section{MSc}

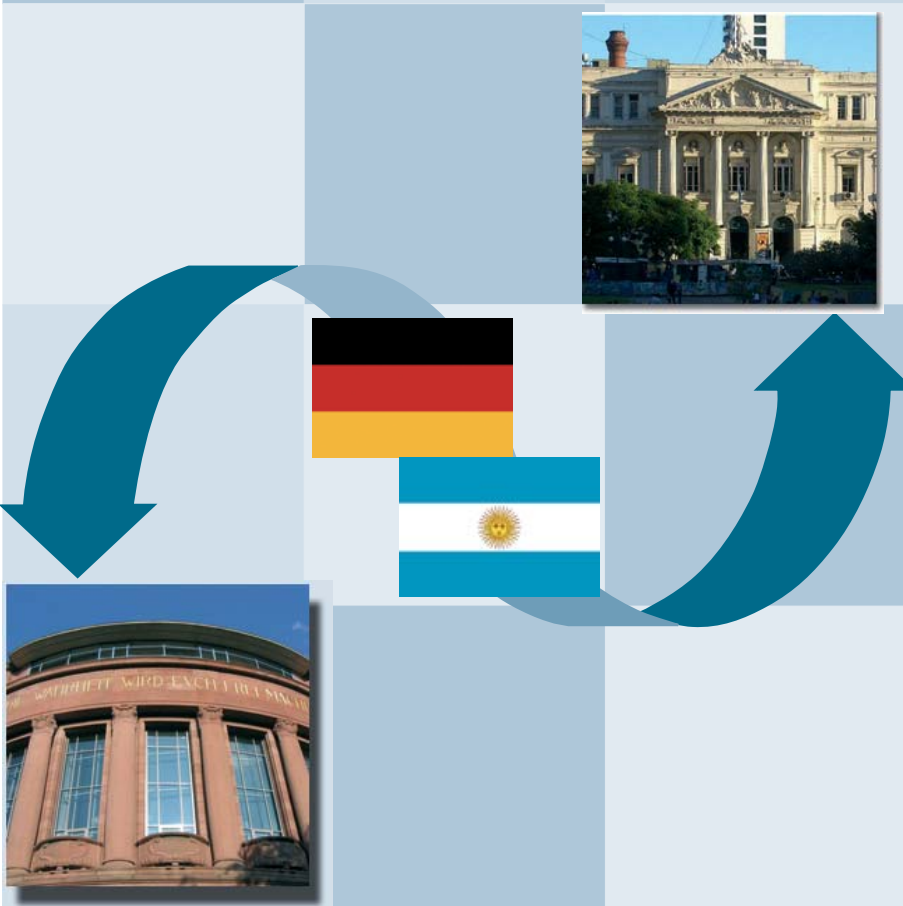


The International Master Program in Biomedical Sciences (IMBS) is a joint program between the University of Freiburg and the Faculties of Medicine, Pharmacy and Biochemistry of the University of Buenos Aires in Argentina. It is supported by the DAAD (German Federal Institution for Academic Exchange) and private philanthropy. The aim of this program is to provide scientific knowledge and state-of-the-art experimental experience to current and emerging biomedical research areas with a focus on translational research and development. The IMBS offers 4 semesters including courses and Master Thesis for the degree "Master of Science (M.Sc.) from the University of Buenos Aires" and a planned "Master of Sciecne (M.Sc.) from the University of Freiburg". Good to excellent results after the first year, qualify for admission to a three-year doctoral project in one of the participating research groups.

The first seven months are carried out in University Buenos Aires. The next five months take place in Freiburg, Germany (Summer school, "the best of Freiburg") including intensive courses, special lectures, and laboratory practice. Upon successful completion of the module courses in Buenos Aires and Freiburg the students will receive a Diploma of Advanced studies of each university.

The Master thesis can be performed either in Buenos Aires or in Freiburg.

All courses are held in English. The academic year starts in February.

The program is open to students from all over the world, who hold a four-year-Bachelor's degree (or equivalent degree) in the biosciences, biochemistry, biology, medicine, or related fields. Admission is only possible to the first segment of the program, not directly to the PhD program.

\section{Schedule of Events 2015}

2nd International Congress

November 20, 2015

DAS Symposium/ IMBS Class 2016

\section{November 24, 2015}

Nobel Laureate Lecture and Symposium 6th Generation/ Buenos Aires

November $25-26,2015$

Master Thesis Defence/ IMBS Class 2015

8

\section{February September}

IMBS Start Trip to Freiburg

Trip to Freiburg

Module I - VIII

BUENOS AIRES FREIBURG
PhD Program

FREIBURG or BUENOS AIRES

Module 1: Biological and Bioenergetic Oxidation

Module 2: Biochemistry and Molecular Biology

Module 3: Physiology, Pharmacology and Toxicology

Module 4: Microbiology, Virology and Immunology

Module 5: Neurobiology

Module 6: Cellular and Molecular Pathology

Module 7: Clinical Medicine

Module 8: Molecular Oncology

Module 9: Laboratory Traineeships

Module 10: Master Thesis

IMBS Class 2013 - Intermediate Exam Freiburg 2013

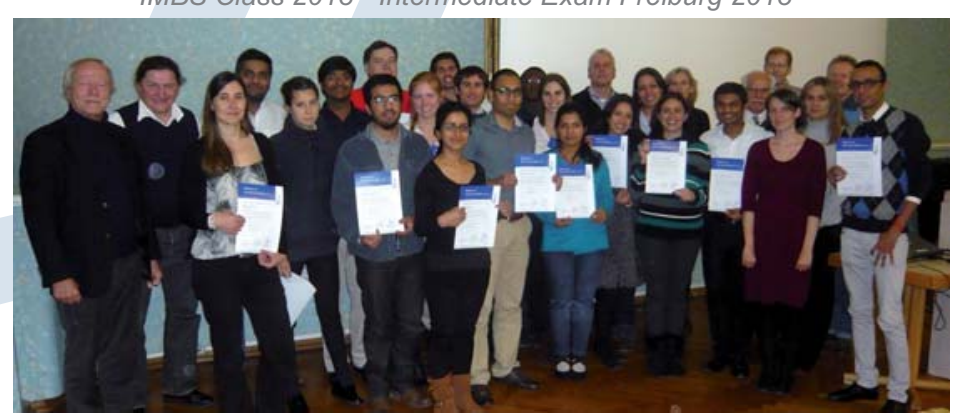

IMBS Class 2012 - Graduation Buenos Aires 2013

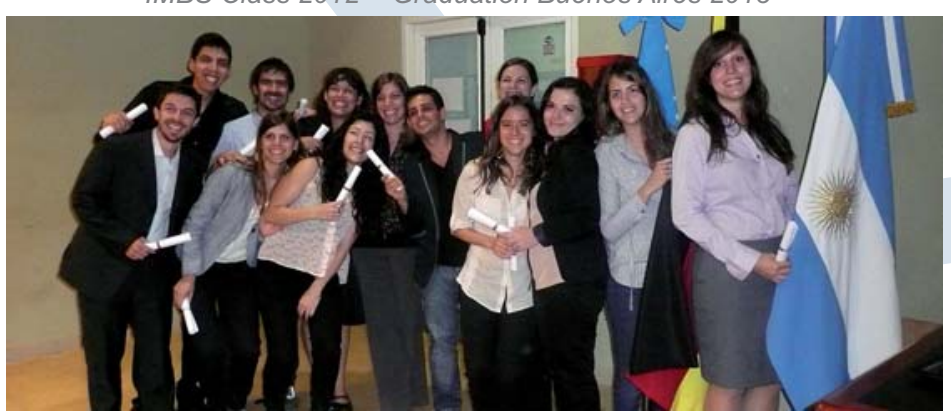

Freiburg is one of the most popular cities in Germany. It is located on the slopes of the Black Forest and is the sunniest city in

Germany. Freiburg is a famous center of academics and research. As one of the oldest universities in Germany, the Albert Ludwigs University of Freiburg (ALU) celebrated its 550 year anniversary in 2007 and is one of Germany's most prestigious and a leading research as well as teaching institution in Europe.

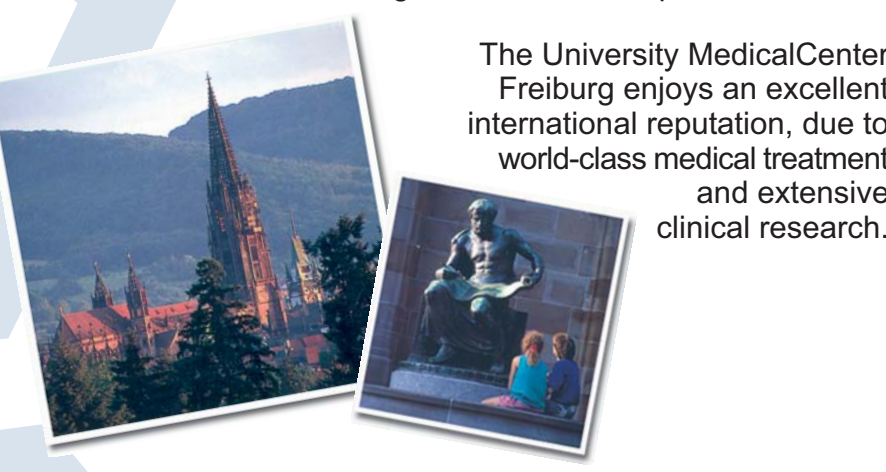

\section{Buenos Aires}

Buenos Aires is the capital of Argentina, the country's largest city and the third largest city in Latin America. Located on the shore of the Río de La Plata, Buenos Aires has always been an open hearted city. It is a modern, dynamic and radiant city that feature the european architecture of its founders. Buenos Aires enjoys perennial a mild climate. It has an intense cultural life where tango long coffee "klatches" and football (soccer) are essential elements in its people's daily lives.

The University of Buenos Aires (UBA) was founded in 1821

At present, it represents a well known prestigious place for the training of professionals with ove 6650 teachers and more than 100.800 students divided in 13 Faculties. Within the area of science and technology, the University of Buenos Aires has an outstanding structure made up

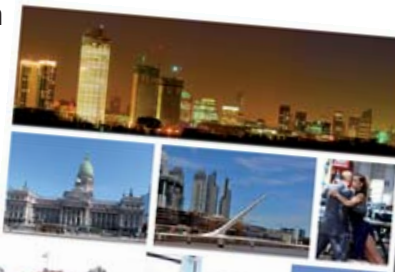
research projects financed by the University, the National Agency of Science and Technology, the CONICET, and other organizations.

The exchange with foreign researches, teachers and students and the design of projects of common interest are some of UBA's main aims. 